\title{
АРХЕОЛОГИЧЕСКИЕ ИССЛЕДОВАНИЯ В УЩЕЛЬЕ БОРАЛДАЙ в 2019 году
}

\author{
(C) 2020 г. Б. А. Байтанаев, А. А. Горячев, Т. А. Егорова, \\ А. Б. Байтанаева, Е. Б. Байтанаев, М. А. Чернов
}

В статье рассматриваются результаты исследований, проводившихся в долине реки Боралдай в полевом сезоне 2019 г. В пещере Туттыбулак-I произведены археологические раскопки пространства у входа в пещеру и вдоль юго-восточной стенки. У входа в пещеру была расчищена конструкция фундамента изгороди (перегородки), перекрывающей вход в пещеру по центру, и конструкция печи тандырного типа раннего средневековья. Вдоль юго-восточной стенки пещеры расчищены каменные плиты, которые в три яруса возвышались над дном раскопа. Они образовались в результате падения разновременных отслоений от стенок и потолка пещеры. В южной части пещеры найдены фрагменты конструкций древнего воздуховода и металлургической печи раннего железного века. Материал, обнаруженный в разных частях и слоях раскопа, представлен фрагментами металлургических шлаков, металлическим наконечником стрелы, керамикой, костяными и каменными инструментами.

Ключевые слова: археология, Каратау, ущелье Боралдай, эпоха бронзы, ранний железный век, средневековье, пещера, печь, воздуховод, орудия труда, керамика

\section{Введение}

В полевом сезоне 2019 г. были продолжены исследования археологических памятников ущелья Боралдай. Рекогносцировочными раскопками охвачены курган раннего железного века по правому берегу одноименной реки в месте ее слияния с рекой Кошкарата и пещера карстового происхождения Туттыбулак-I, расположенная в боковом ущелье в 300 м к северозападу от его устья. Предыдущими исследованиями было установлено, что пещера функционировала в эпоху бронзы и в раннем железном веке в качестве стоянки для охотников и собирателей. На поздних этапах древнего периода она используется ранними металлургами для выплавки кричного железа, а в средневековую эпоху с перерывами функционировала как ма- стерская по выплавке металла [Байтанаев, Горячев и др., 2018]. В результате дополнительной археологической разведки древних памятников были зафиксированы два новых поселения и два могильника древних периодов, что позволило дополнить известную археологическую карту данного микрорайона (рис. 1). Поселения расположены в глубине бокового ущелья близ невысокого горного перевала и скопления петроглифов Жуземды. Они представляли собой серии полуземлянок, устроенных по правому берегу ручья и врезанных в восточные склоны ущелья. Могильники расположены на вершинах небольшого плато и увала по правому берегу р. Боралдай, представляли собой группы из четырех курганов. 


\section{ҚАЗАКСТАН АРХЕОЛОГИЯСЫ № 1 (7) 2020}

\section{Методика исследований}

Основной целью исследований в пещере Туттыбулак-I в 2019 г. стало выяснение ее конструктивных деталей в древности и средневековье, а также функционального назначения плит, расположенных с доисторических времен вдоль юго-восточной стенки, поиск новых материалов и их культурно-хронологическая атрибу- ция с целью определения начальных этапов использования пещеры. В полевом сезоне 2019 г. произведены археологические раскопки пространства у входа в пещеру и вдоль юговосточной стенки. Разрушения, произошедшие с центральной поперечной бровкой в пещере, вынудили произвести прирезку в 1 м к юго-востоку вглубь пещеры. Археологические

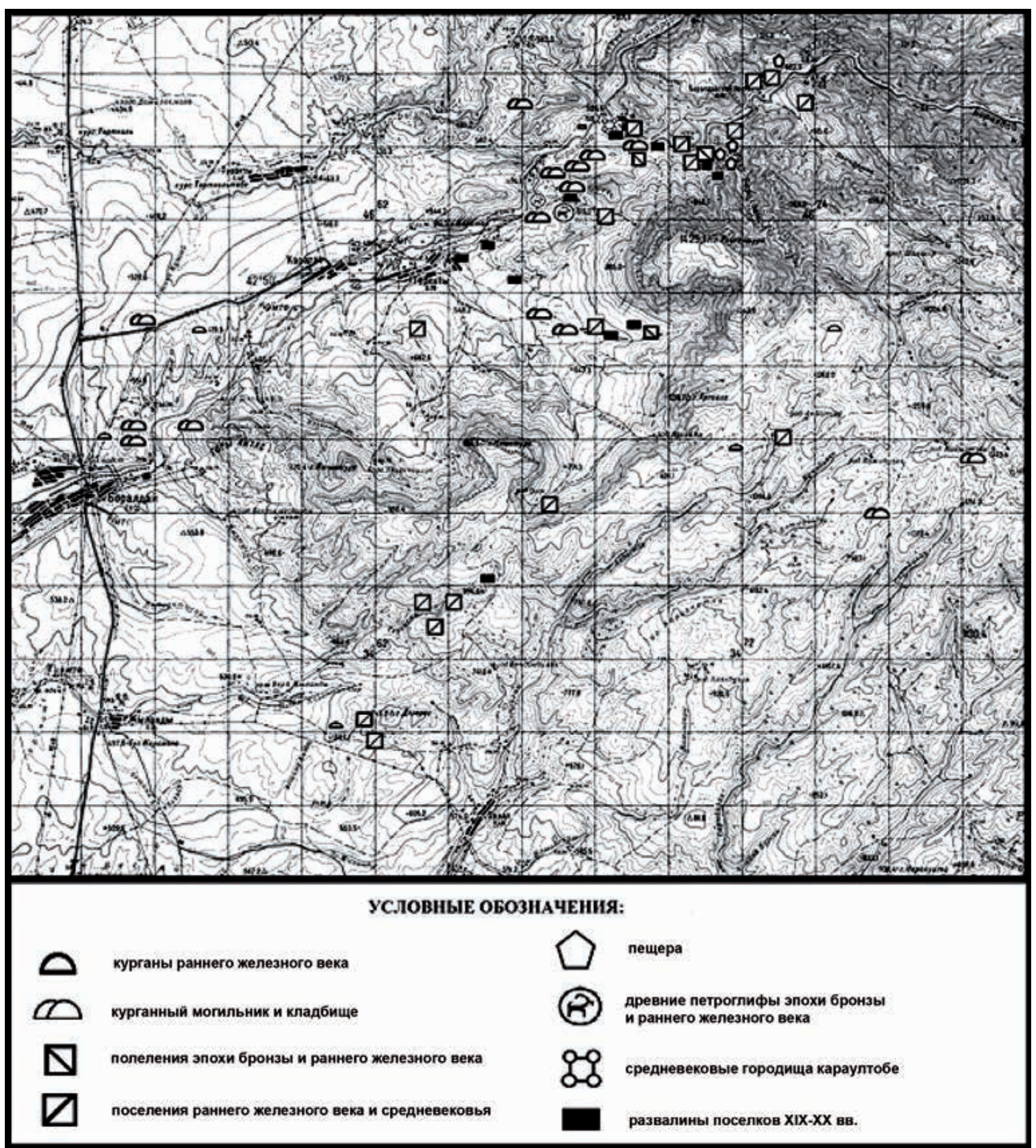

Рис. 1. Карта археологических памятников ущелья Боралдай и прилегающих территорий

Fig. 1. Map of archaeological monuments of Boraldai gorge and adjacent territories 
Байтанаев Б.А., Горячев А.А., Егорова Т.А., Байтанаева А.Б., Байтанаев Е.Б.,

Чернов М.A. Археологические исследования в ущелье Боралдай в 2019 году

раскопки производились методом послойного (20 см) снятия грунта. Был зачищен новый поперечный разрез пещеры размерами 7,5 м в длину и 2 м в глубину. Общие размеры раскопа составили 18×7-9 м. Общая площадь исследованной поверхности пещеры составила примерно 150 кв. м (рис. 2).

Описание материала пещерь Туттыбулак-I

В результате раскопок у входа в пещеру (квадраты А-1 и Б-1) была расчищена конструкция фундамента перегородки, перекрывающей вход в пещеру по центру и в сторону северовосточной стенки в длину 3,5 м, в ширину 1,7 м, в высоту 0,6 м. Кладка фундамента представляла собой три ряда каменных выкладок, скрепленных глиняным раствором. Перегородка ориентирована по оси СВ-Ю3 (рис. 3, 1-2). У каменной стенки и каменной плиты, стоящей вертикально по центру пещеры, обнаружены ямы под опорные столбовые конструкции, заполненные золой и древесным углем (вероятно, в результате сгорания этих конструкций). Судя по вещевому материалу, найденному среди глиняной заливки фундамента, она была сооружена в раннем средневековье. В последующее время фундамент перегородки слегка оплыл внутрь пещеры.

С внутренней стороны перегородки в квадрате -2 была расчищена конструкция печи на глубине 4050 см (рис. 3, 3-4). Печь - тандырного типа небольших размеров диаметром 70 см по дну, 80 см в серединной части. Яма печи заполнена золой, древесным углем и фрагментами костей животных. Вероятно, она служила для приготовления пищи ремесленниками, работавшими в пещере. Высота печи составляла около $80 \mathrm{~cm}$ - на это расстояние наблюдаются разваливши- еся обломки глиняных стенок с югозападной и юго-восточной сторон от нее. Данное сооружение не было соединено ни с одной системой воздуховодов, которые были устроены для металлургических печей. Слой, в котором яма обнаружена, и вещевой материал (керамика) позволяют датировать эту печь ранним средневековьем.

Вдоль северо-восточной стенки пещеры (квадраты B-1 и В-7) были расчищены каменные плиты, которые в три яруса возвышались над дном раскопа (220 см от уровня поверхности) на высоту 3-3,5 м (рис. 3, 5-6). Ярусы каменных плит образовались в результате падения разновременных отслоений от стенок и потолка пещеры в доисторическое время. Поверх плит 2-3 ярусов находились крупные блоки известняка, вероятно, также отслоения от потолка пещеры. Два таких блока зафиксированы в квадратах В-2 и В-3, один в квадрате В-4 и еще один на границе квадратов B-5 и B-6. Пространство плит закрыто вдоль стенки пещеры каменными блоками различных размеров, в результате чего образовались многочисленные ниши и полочки, при зачистке на которых в основном зафиксировались кости мелких грызунов и птиц.

В квадратах В-4 - В-6 верхний ярус каменных плит образован в виде площадки подовальной формы, размерами примерно 7,5×3 м. Пространство между стенкой пещеры было выровнено за счет укладки квадратных и прямоугольных каменных блоков средних размеров. В результате образовалось относительно ровное пространство и удобное для устройства мест отдыха и сна. В 2018 году здесь был обнаружен заклад металлических инструментов и медный фельс VIII в. правителей Чача, что позволяет дати- 


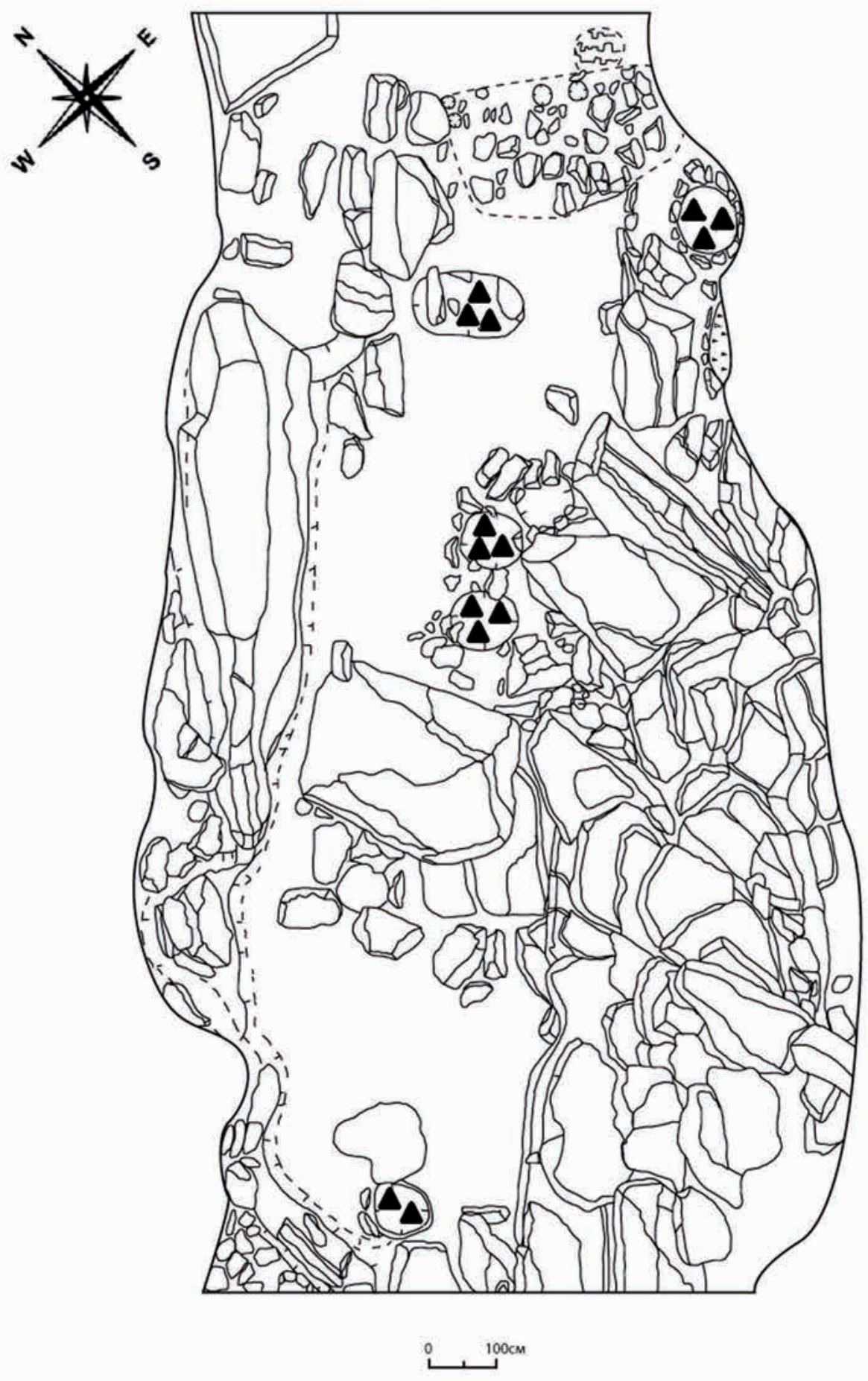

Рис. 2. План раскопа 2019 г. пещуеры Туттыбулак-I

Fig. 2. Excavations' plan 2019 of Tuttybulak Cave-I 
Байтанаев Б.А., Горячев А.А., Егорова Т.А., Байтанаева А.Б., Байтанаев Е.Б.,

Чернов М.A. Археологические исследования в ущелье Боралдай в 2019 году
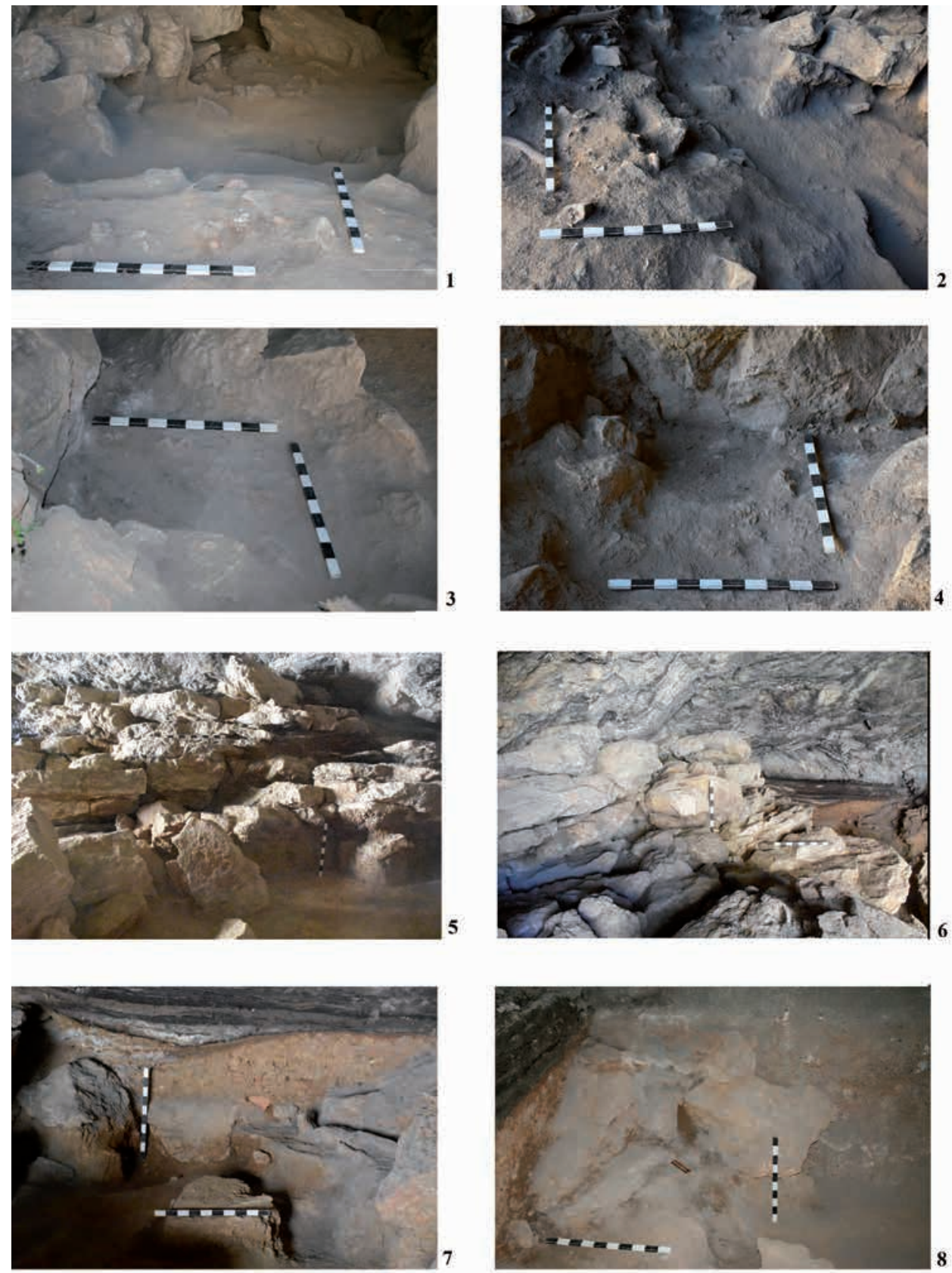

Рис. 3. Раскоп 2019 года в пещере Туттыбулак-I: 1, 2 - каменно-земляная перегородка у входа в пещеру; 3, 4-развал печи у юго-восточной стенки пещеры, 5, 6-завал каменных плит, отслоившихся от юго-восточной стенки и потолка пешеры; 7 - развал металлургической печи в южной части раскопа;

8 - ррагмент воздуховода у северо-западной стенки пещеры. Фото авторов

Fig. 3. Excavation 2019 in Tuttybulak Cave-I: 1, 2 - stone-earth septum near cave s entrance; 3, 4-furnace remains near South-Eastern cave's wall; 5, 6-block of stone slabs peeling from the southeast wall and ceiling of the cave; 7 -remains of metallurgical furnace in South part of excavation; 8 - air duct's fragment near South-West cave's wall. Authors's photos 
ровать кладку на верхнем горизонте ранним средневековьем [Байтанаев, Горячев и др., 2018: рис. 4, 5].

Второй ярус каменных плит, связанный с более масштабным разрушением юго-восточной стенки пещеры, занимает площадь вдоль нее по всему центральному залу примерно 13 м в длину. Эти плиты лежат в два слоя, местами плотно примыкая друг к другу. Пространство между ними было заполнено грунтом пещеры, создавая достаточно удобные проходы как через территорию зала, так и к верхним плитам. Вероятно, данный участок пещеры использовался средневековыми металлургами именно в этих целях.

Третий ярус каменных плит наиболее ранний среди открытых, находится на глубине 1,5-2 м от верхнего яруса. Это наиболее массивные камни, достигающие в длину от 3,5-7,5 м. Центральная плита откололась с участком не только стенки, но и потолка пещеры. В результате чего она создала «козырек», перекрывавший трехметровый ширины проход от входа в гротовую часть почти по центру основного зала пещеры. Изначальные размеры плиты 5,5×3,5 м. В древности в результате падения на «козырек» крупных валунов он обломился приблизительно по центру. Упавшая часть спровоцировала обвал плит-подпорок, под которыми были найдены кости черепа человека, возле которого обнаружены наконечники стрел позднебронзового и раннего железного века.

После снятия крупного каменного блока, упавшего на второй ярус плит у северо-восточной стенки, в квадратах Б-4 - В-4 обнаружен завал из каменных плит средних размеров, закрывший пространство между от- дельными плитами третьего яруса центральной части пещеры. При их зачистке на уровне второго яруса были обнаружены фрагменты костей животных и средневековой керамики разных этапов (от раннего средневековья до Нового времени). На уровне плит третьего яруса фиксировались фрагменты керамической посуды (горшки, плошки, кувшины раннего железного и бронзового веков). Под плитами третьего яруса обнаружены фрагменты передней части нижней челюсти и черепа человека (вероятно, продолжение костных останков человека, обнаруженного в 2018 г.). Здесь же между камнями зафиксирован сильно разрушенный железный (?) наконечник стрелы.

После снятия крупной каменной плиты в квадратах А-6 - А-7 - Б-6 - Б-7, на глубине 150-170 см от дневной поверхности, обнажились фрагменты конструкции металлургической печи раннего железного века, которая представляла собой яму диаметром 70-80 см с толстыми глинобитными стенками (10-15 см). С северной стороны найдена рухнувшая стена печи длиной около 1 м и толщиной до $15 \mathrm{~cm}$ (рис. 3,7$)$. Основание печи обложено мелкими каменными плитками. Отмечено место соединения воздуховода к ее нижней части. В квадрате А-7 расчищена конструкция части основного воздуховода с боковыми ответвлениями. Конструкция представляла собой каменную глыбу известняка, прислоненного к юго-западной стенке пещеры длиной более 3,5 м и высотой 2,2 м (рис. 3,8$)$. Верхняя часть ее была тщательно забутована глиной и перекрыта каменными плитками речного происхождения. Конструкция воздуховода, ведущего к печи, устроена на боковом крае рухнувшей каменной плиты. 
Байтанаев Б.А., Горячев А.А., Егорова Т.А., Байтанаева А.Б., Байтанаев Е.Б.,

Чернов М.A. Археологические исследования в ущелье Боралдай в 2019 году

Материал, обнаруженный в разных частях и слоях раскопа, представлен фрагментами металлургических шлаков, металлическим наконечником стрелы, керамикой, костяными и каменными инструментами. Каменные орудия труда представлены серией терочных инструментов треугольной, овальной и прямоугольной форм, фрагментом зернотерки и группой камней шаровидной (болас), округло-овальной и треугольной форм, вероятно, использовавшихся как пестымолотки (рис. 4, 1-9). Лощила-терочники изготовлены из речной гальки, рабочий край их сильно заглажен. Торцевые стороны пестов слегка уплощены, со следами сработанности, у шаровидных изделий рабочий край обычно один.

Среди находок в центральной части пещеры под скальной плитой на глубине 150 см был обнаружен второй трёхгранный черешковый железный наконечник стрелы очень плохой сохранности (рис. 4, 13). Вероятно, перо имело трехлопастное сечение, которое не сохранилось. Длина изделия 6 см. Судя по схожести с прошлогодней находкой, наконечник

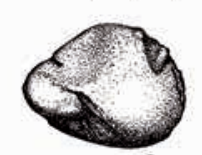

стрелы относится к середине I тыс. до н.э. [Байтанаев, Горячев и др., 2018, рис. 4,17$]$.

Интересную серию составляют фрагменты костей животных, особенно, обнаруженных под каменными плитами между разными ярусами завалов от юго-восточной стенки. Там преобладают кости диких животных, как объектов охоты, так и, вероятно,
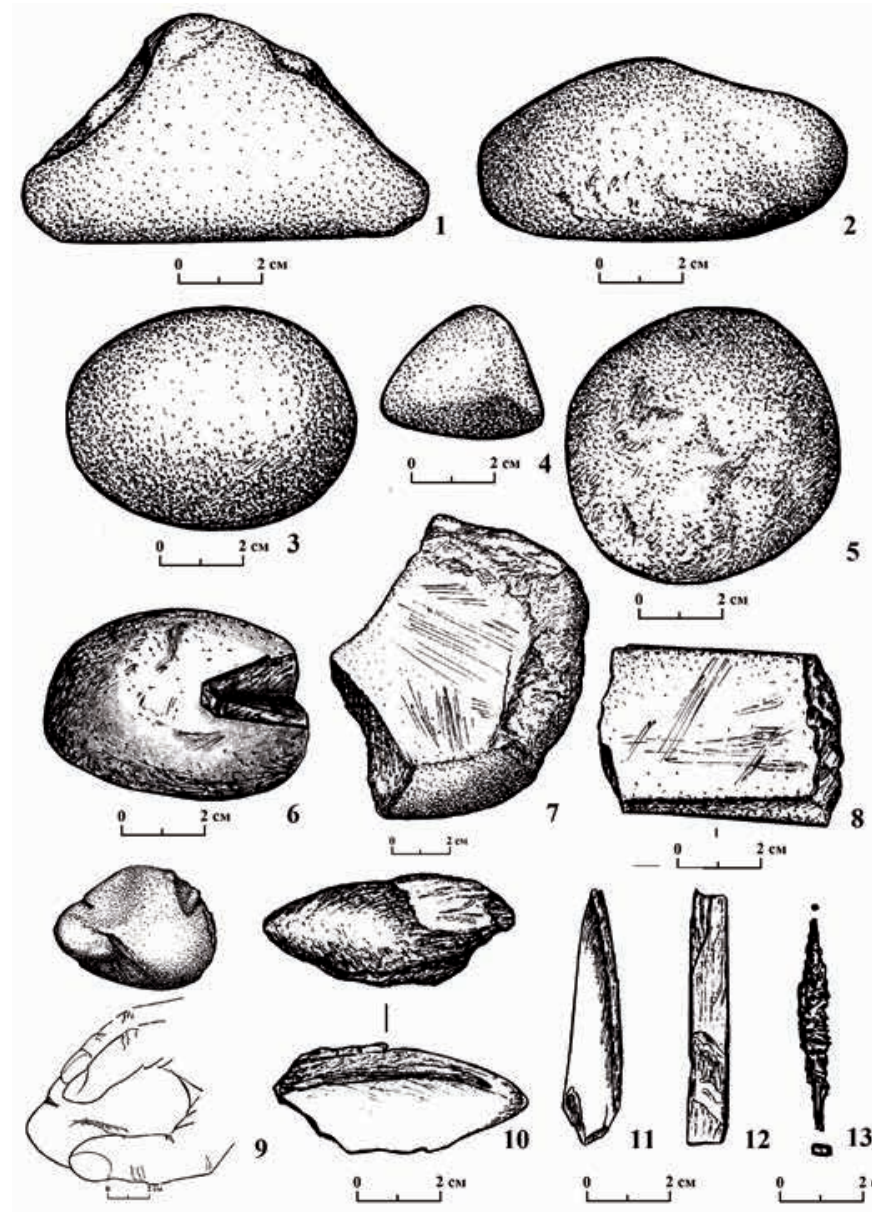

5
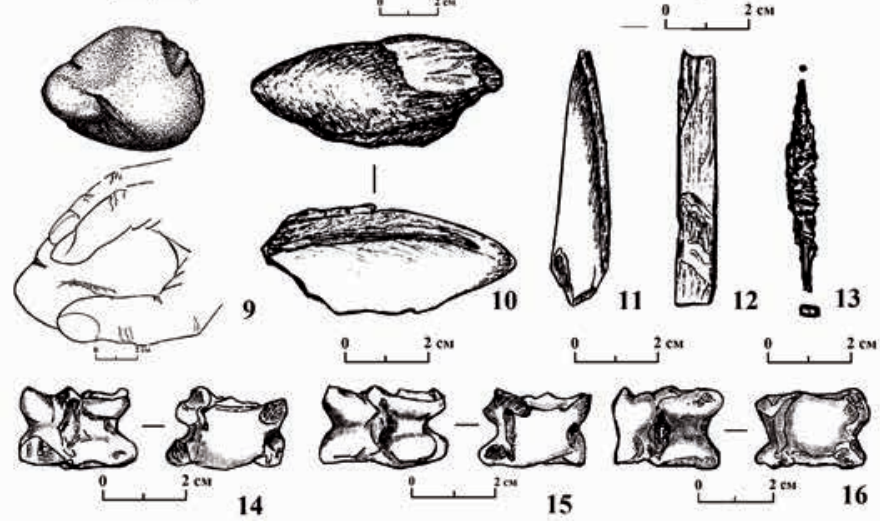

Рис. 4. Вещевой материал из раскопа 2019 года в пещере Туттыбуллак-I: 1-9-камень, 10-12, 14-16-кость;

$$
13 \text { - железо }
$$

Fig. 4. Material from excavation 2019 in Tuttybulak Cave-I: 1-9-stone, 10-12, 14-16-bone; 13 - iron 


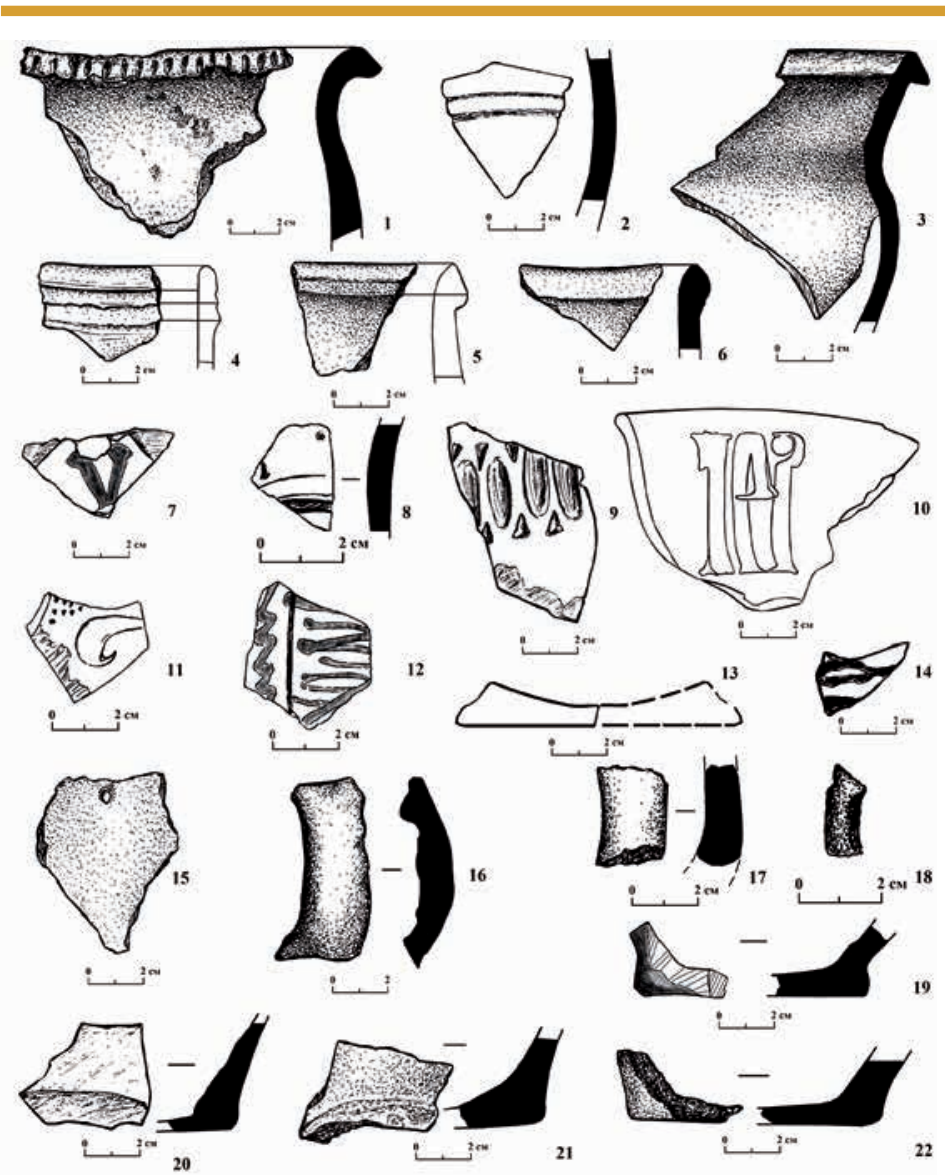

Рис. 5. Средневековая керамика из раскопа 2019 года в пешере Туттыбулак-I

Fig. 5. Middle Age ceramics from excavation 2019 in Tuttybulak Cave-I

редины заготовки стесыванием кости придавалась узкая удлиненная форма. Их верхние концы имеют форму усеченной пирамиды с площадкой четырехугольной формы. Нижний рабочий край заострен. Эта группа изделий чаще всего обнаруживается во фрагментированном состоянии, вероятно, вследствие их длительного или интенсивного применения. Астрагалылощила, в отличие от найденных здесь ранее, имеют следы незначительной сработанности на торцевых сторонах, что говорит о недлительном их использовании.

Н а и б о л е е многочисленную серию составляют

обитавших в пещере в глубокой древности. Также обнаружены части расколотых костей крупного и мелкого рогатого скота. Некоторые из них обгоревшие. Ряд костей, обнаруженных на разных уровнях раскопа, имеют следы обработки и применения в качестве инструментов - проколок, скребков, астрагалов-лощил (рис. 4, 10-12, 14-16).

Проколки и скребки изготавливались в основном из фрагментов трубчатых костей животных. Как правило, у проколок с обоих концов от се- фрагменты средневековых керамических сосудов (рис. 5). Она представлена в основном кухонной и тарной посудой. Керамические обломки составляют различные части сосудов котлов, кувшинов, горшков, хумов, хумчи, чаш и блюд от раннего до позднего средневековья. Крупная тарная посуда представлена фрагментами венчиков и стенок хумов. Венчики валикообразные, крупный хум имеет резко отогнутую наружу закраину горловины.

Кухонная посуда представлена разными формами и типами глиня- 
Байтанаев Б.А., Горячев А.А., Егорова Т.А., Байтанаева А.Б., Байтанаев Е.Б.,

Чернов М.A. Археологические исследования в ущелье Боралдай в 2019 году

ных сосудов. Вся керамика выполнена на гончарном круге. Фрагменты некоторых кувшинов и горшков покрыты ангобом. Аналогичные по технологии изготовления и форме сосуды встречаются на средневековых городищах Средней Азии и Южного Казахстана [Смагулов, 2011, с. 387]. Большая часть посуды была местного производства и относится к Караханидскому времени (X-XIII вв.). Часть фрагментов блюд глазурована. Судя по арабографичной орнаментации (рис. 5, 7, 10, 12), схожей с материалами из пещеры Акмечеть [Байтанаев, 2011 , с. 146 , рис. 4, 15], данная посуда относится уже к послемонгольскому времени для данного региона [Акишев и др., 1987, с. 165, 167].

Значительную часть керамического материала из слоев раскопа в глубине и центральной части пещеры составили фрагменты сосудов эпохи бронзы и раннего железного века (рис. 6). Керамика раннего железного века найдена преимущественно в слоях от 100 до120 см в глубину и представлена фрагментами горшков, кувшинов, чашек и мисок, изготовленных лепным способом из глины серочерного и кирпичного цвета (рис. 6, 9-18). Большую часть находок составляют венчики сосудов с вертикальными налепными ручками. Для этого времени такая керамика отмечена у северных склонов хребта Каржантау [Байтанаев, 2011, с. 77-79]. Наиболее близкие аналогии керамике раннего железного века пещеры Туттыбулак-I зафиксированы в материалах поселений и могильников Жетысу позднесакского времени Тургень-II и Осербай-I, Тузусай, Цыганка-8 и Талдыбулак-2 [Акишев, Кушаев, 1963, табл. XI; Байпаков, Марьяшев, 2001, с. 53-65; Байпаков, 2008, с. 74-79; Горячев, Егорова, 2015].
Керамика эпохи бронзы обнаружена в раскопах центральной и южной частях пещеры на глубине 120 150 см, вплоть до 180-200 см (рис. 6, 1-8). Она представлена фрагментами крупных плоскодонных сосудов баночной и горшковидной форм. Большинство горшковидной посуды имеют плавную профилировку плечика (рис. 6,8$)$ и сильно раздутое тулово. Ряд фрагментов имеет характерные налепные валики под венчиками и по тулову. На территории Южного Казахстана и Жетысу подобная керамика встречается в материалах поселений, относящихся к XII-X вв. до н.э. [Байтанаев, 2011, с. 17, рис. 1, 6; Марьяшев, Горячев, 2017, рис. 5, 6].

Подобная серия каменных инструментов хорошо известна в материалах древних поселений Центрального Казахстана и Жетысу и может относиться к поселениям и средней, и поздней бронзы данных регионов [Кадырбаев, Курманкулов, 1992, с. 133 137; Горячев, 2013, с. 348-370].

Обсуждение результатов

Основной целью исследований в пещере Туттыбулак-I было выяснение конструктивных деталей использования ее в древности и средневековьеи изучение новых материалов раскопок с целью их культурно-хронологической атрибуции. В результате полевых исследований в 2019 г. на входе в пещеру Туттыбулак-І выявлены конструкции перегодки и печи для приготовления пищи, которые датируются по обнаруженному в них вещевому материалу ранним средневековьем. Установлено, что камни, расположенные вдоль северо-восточной стенки, представляют собой завалы, отколовшихся каменных плит от потолка и стен пещеры. На уровне раскопа отмечено 

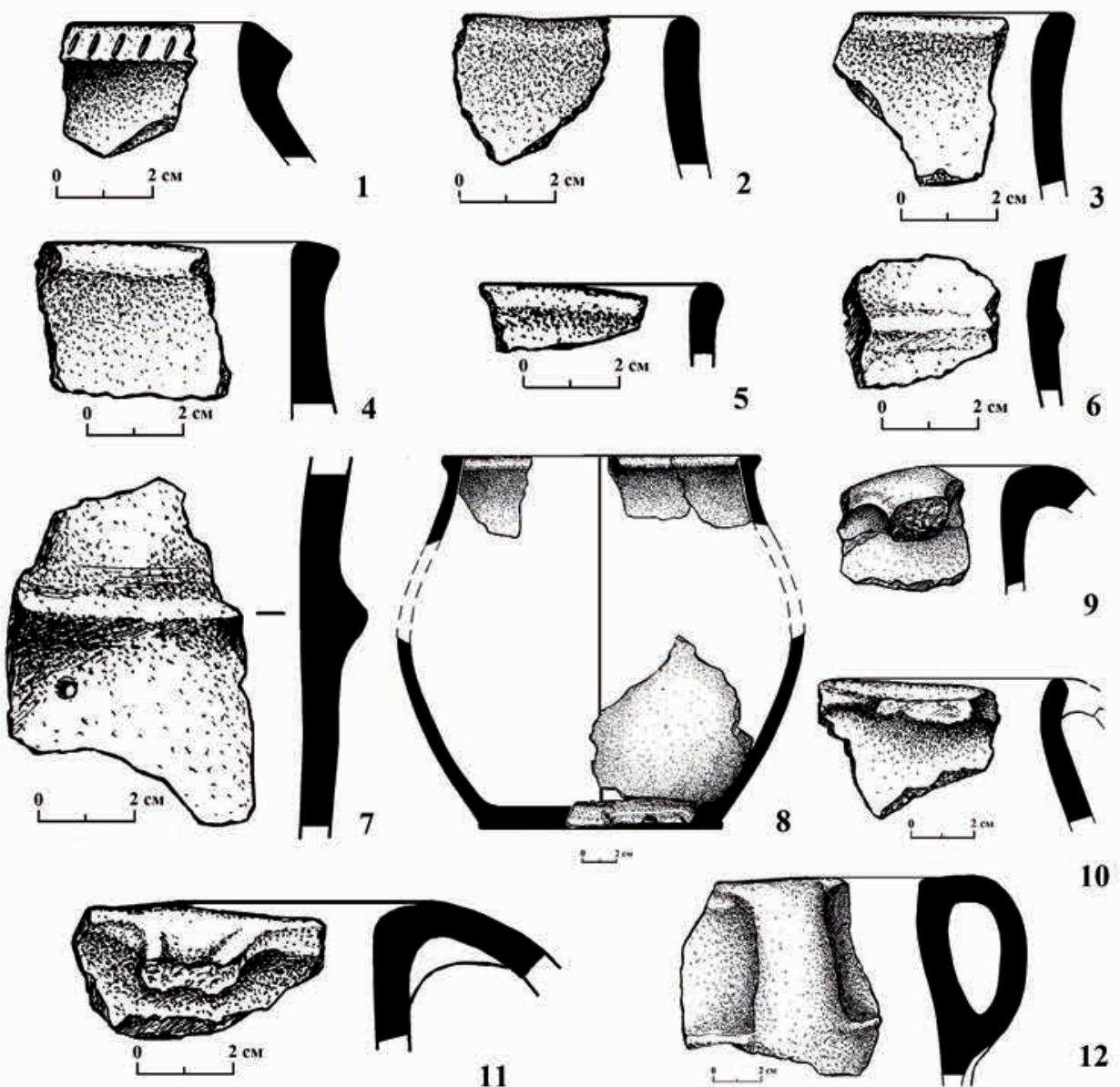

10

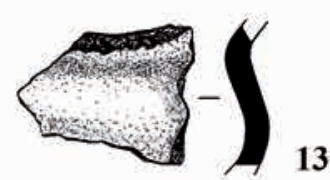

11

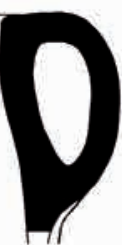

12
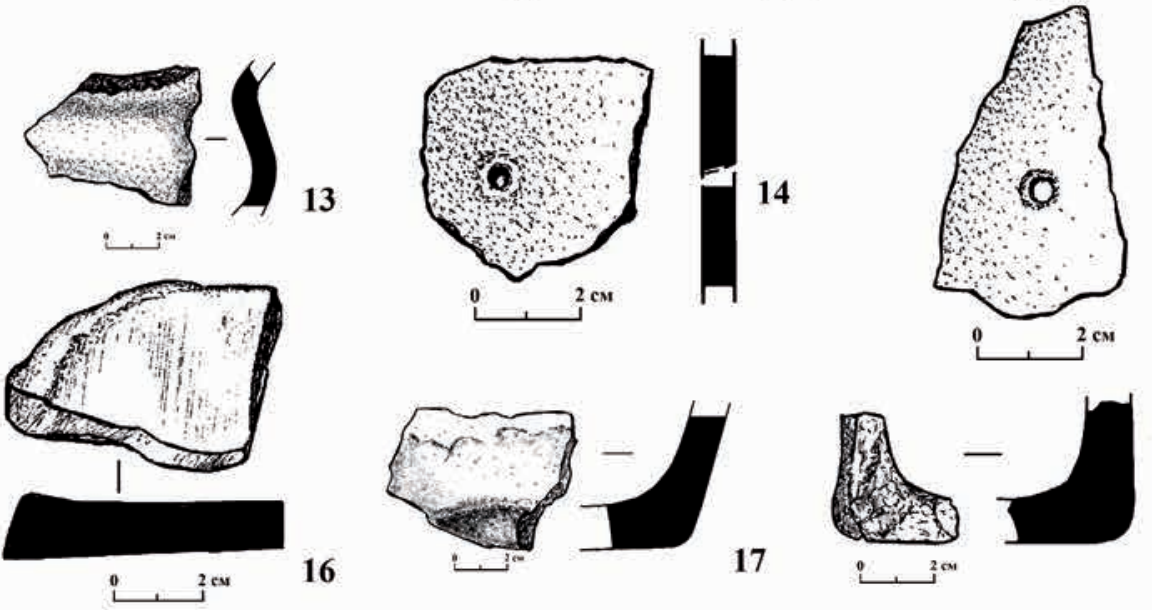

Рис. 6. Древняя керамика из раскопа 2019 года в пещере Туттыбулак-I:

1-8 - эпоха бронзы; 9-18-ранний железный век

Fig. 6. Ancient ceramics from excavation 2019 in Tuttybulak Cave-I:

1-8 - the Bronze epoch; 9-18 - the Early Iron Age 
Байтанаев Б.А., Горячев А.А., Егорова Т.А., Байтанаева А.Б., Байтанаев Е.Б.,

Чернов М.A. Археологические исследования в ущелье Боралдай в 2019 году

пока только их три яруса. При расчистке между плитами разных ярусов отмечены материалы, датируемые от позднего средневековья до бронзового века. Костные останки животных, которые можно отнести к палеонтологическим находкам, позволяют предположить, что данные завалы образовались до начала использования пещеры человеком.

В центральной части пещеры на нижних уровнях расчищена конструкция металлургической печи, соединенной с системой воздуховода, идущего от входа в пещеру. Печь была завалена крупной каменной плитой, отколовшейся от потолка пещеры. Ее стратиграфическое положение и вещевой материал, зафиксированный на данном уровне, позволяют датировать сооружение ранним железным веком. Датировка исследованных нижних слоев раскопа поздним этапом эпохи бронзы приемлема и для других находок бронзового века из пещеры. Однако результаты контрольного шурфа у входа в пещеру позволяют предполагать, что в андроновский период бронзового века пещера также использовалась древними охотниками ущелья Боралдай. Наличие значительного культурного слоя на глубину еще минимум 1,5 м позволяет считать дальнейшие исследования памятника перспективными.

\section{Bblвodbl}

Древнее и средневековое население ущелья Боралдай занималось металлургическим производством. С этой целью еще в древности группы скотоводов и ремесленников отделяются от крупных селений земледельцев, расположенных в нижней части ущелья, и перебазируются вверх по ущелью, где имелись в достатке необходимое сырье, а также возможности для дополнительных видов хозяйственной деятельности - скотоводство, садоводства и огородничества. В качестве одной из мастерских по выплавке железа, как минимум с середины I тыс. до н.э., использовалась пещера Туттыбулак-I. Начиная с раннего средневековья, пещера используется достаточно интенсивно, что порой приводило к разрушению отдельных участков ее стен и потолка.

Материалы археологических исследований показывают, что взаимосвязи древнего населения ущелья сохраняются на протяжении всех исторических эпох, позволяя создать здесь локальную самодостаточную экономическую модель по обеспечению населения всеми необходимыми продуктами жизнеобеспечения. Внутри этой модели местность в районе слияния рек Кашкарата и Боралдай становится определенным административно-сакральным центром, где располагались наиболее крупные селения (в средневековье караултобе), могильники и святилища с петроглифами (Жуземды). Их дальнейшее изучение позволит осветить вопросы хозяйственно-культурного развития древнего и средневекового населения региона.

\section{ЛИТЕРАТУРА}

1. Акишев К.А., Байпаков К.М., Ерзакович Л.Б. Отрар в XII-XV веках. Алма-Ата: «Наука» КазССР, 1987. 256 с.

2. Акишев К. А., Кушаев Г.А. Саки и усуни долины реки Или. Алма-Ата: «Наука» КазССР, 1963. $310 \mathrm{c}$. 
3. Байпаков К.M. Поселения саков и усуней на территории Жетысу и Алматы. Алматы: «Credo», 2008. 173 с.

4. Байпаков К.M., Марьямев А.Н. Новые данные по изучению поселений эпохи раннего железного века в Жетысу // Известия НАН РК. Сер. обществ. наук. 2001. № 1 (230). C. 53-65.

5. Байтанаев Б.А. Древности Бургулюка. Алматы: Институт археологии им. А.Х. Маргулана, 2011. 224 с.

6. Байтанаев Б.А., Горячев А.А., Егорова Т.А., Ергешбаев А.А., Байтанаева А.Б, Байтанаев Е.Б. Археологические исследования в пещере Туттыбулак в 2018 году // Қазақстан археологиясы. 2018. № 1-2. С. 272-287.

7. Горячев A.A. Вопросы типологии и хронологии поселений эпохи бронзы на северных склонах Заилийского Алатау // Бегазы-дандыбаевская культура Степной Евразии: сб. науч. ст., посвящ. 65-летию Ж. Курманкулова. Алматы: Институт археологии им. А.Х. Маргулана; НИЦИА «Бегазы-Тасмола», 2013. С. 348-370.

8. Горячев A.A., Егорова T.A. Поселения раннего железного века в ущелье Бутаковка (на юго-восточной окраине города Алматы) // Сакская культура Сарыарки в контексте изучения этносоциокультурных процессов степной Евразии: сб. науч. ст., посвящ. памяти К.А. Акишева. Алматы: НИЦИА «Бегазы-Тасмола», 2015. С. 90-99.

9. Кадырбаев М.К., Курманкулов Ж. Культура древних скотоводов и металлургов Сары-Арки. Алма-Ата: «Ғылым», 1992. 247 с.

10. Марьямев А.Н., Горячев А.А. Вопросы изучения поселений эпохи бронзы Северного Притяньшанья // Электронный научный журнал «е-history.kz». 2017. № 3 (11). URL: http://edu.e-history.kz/ru/publications/view/723 (дата обращения 02.02.2020).

11. Смагулов Е.А. Древний Сауран. Алматы: АО «АБДИ Компани», 2011. 436 с.

\section{Сведения об авторах:}

Байтанаев Бауыржан Абишевич - доктор исторических наук, академик НАН РК, директор, Институт археологии им. А.Х. Маргулана (г. Алматы, Казахстан); baytanaev@mail.ru

Горячев Александр Анатольевич - старший научный сотрудник, Институт археологии им. А.Х. Маргулана (г. Алматы, Казахстан); aga.2805@mail.ru

Егорова Татьяна Александровна - специалист-филолог, Институт археологии им. А.Х. Маргулана (г. Алматы, Казахстан); ega.0108@mail.ru

Байтанаева Асель Бауыржановна - бакалавр-художник, Институт археологии им. А.Х. Маргулана (г. Шымкент, Казахстан); baitasel@mail.ru

Байтанаев Елнар Бауыржанович - инженер, Институт археологии им. А.Х. Маргулана (г. Алматы, Казахстан); ebaitanaev@mail.ru

Чернов Михаил Алексеевич - инженер-художник, Институт археологии им. А.Х. Маргулана (г. Алматы, Казахстан); mihalapych@yandex.kz

\section{9 жЫЛҒЫ БОРАЛДАЙ ШАТҚАЛЫНДАҒЫ АРХЕОЛОГИЯЛЫҚ ЗЕРТТЕУЛЕР}

\section{Б. Ә. Байтанаев, А. А. Горячев, Т. А. Егорова, Ә. Б. Байтанаева, Е. Б. Байтанаев, М. А. Чернов}

Мақалада Боралдай өзені аңғарындағы 2019 жылғы далалық кезеңдегі зерттеу қорытындысына арналған. Тұттыбұлақ-1 үңгірінің аузынан бастап оңтүстік шығыс бойымен археологиялық қазба жүргізілді. Қазбаның жалпы өлшемі $18 \times 7$ (7-9) м.

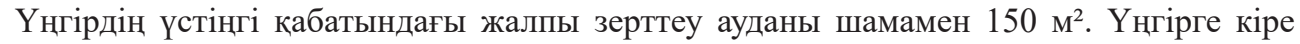
берісте қоршау (қалқа) іргетасының конструкциясы тазаланды, үңгірге кіретін жердің 
ортасында және ерте ортағасырлық тандыр түріндегі пештің конструкциясын жабады. Үңгірдің оңтүстік-шығыс қабырғасын бойлай 3-3,5 м биіктікке қазбаның түбінен (бетінің деңгейінен 220 см) үш қабатқа көтерілген тас плиталар тазаланды. Олар үңгірдің қабырғалары мен төбесінен әр түрлі кезеңдік қатпарларының және олардың құлауының нәтижесінде пайда болды. Үңгірдің оңтүстік бөлігінде ежелгі ауа үрлегіш және ерте темір дәуіріндегі металургиялық пеш конструкцияларының сынықтары табылды. Қазбаның әр түрлі бөліктері мен қабаттарынан табылған заттар металургиялық қалдықтардың сынықтары, жебенің метал ұштығы, керамика, сүйек және тас құралсаймандармен көрінеді.

Түйін сөздер: археология, Қаратау, Боралдай шатқалы, қола дәуірі, ерте темір дәуірі, ортағасырлар, үңгір, пеш, ауа үрлегіш, еңбек құралы, керамика

\section{ARCHEOLOGICAL RESEARCHES IN BORALDAY GORGE in 2019}

\section{B. A. Baitanayev, A. A. Goryachev, T. A. Egorova, A. B. Baitanayeva, E. B. Baitanayev, M. A. Chernov}

This article is devoted to the results of researches in the Boralday river valley in the 2019 field season. In the cave Tuttybulak-1 at the entrance to the cave and along the southeastern wall there were made archaeological excavations of the room. The total size of the excavation was $18 \times 7(7-9) \mathrm{m}$. Total area of the investigated surface of the cave was approximately $150 \mathrm{~m}^{2}$. At the entrance to the cave, the foundation structure of the fence (partition) was cleared, blocking the entrance to the cave. In the center there was structure of the tandoor type furnace of the Early Middle Ages. Along the southeastern wall of the cave, stone slabs were cleared. They were overtopped in three tiers over the bottom of the excavation $(220 \mathrm{~cm}$ from the surface level) to a height of 3-3.5 m. These slabs have formed because of differenttime delamination from the walls and ceiling of the cave and their fall. In the southern part of the cave, fragments of the ancient air duct and metallurgical furnace of the Early Iron age were found. The materials, which were found in different parts and layers of the excavation were fragments of metallurgical slag, metal arrowhead, ceramics, bone and stone tools.

Keywords: archaeology, Karatau, Boralday gorge, the Bronze epoch, the Early Iron Age, the Middle Ages, furnace, air duct, tools, ceramics

\section{REFERENCES}

1. Akishev, K. A., Baipakov, K. M., Erzakovich, L. B. 1987. Otrar v XII-XV vekah (Otrar in the XII-XV centuries). Alma-Ata: "Nauka" Publ. (in Russian).

2. Akishev, K. A., Kushayev, G. A. 1963. Saki i usuni doliny reki Ili (Saka and Wusun from valley of Ili river). Alma-Ata: "Nauka" Publ. (in Russian).

3. Baipakov, K. M. 2008. Poseleniya sakov i usuney na territorii Jetysu i Almaty (Saka and Wusun settlements on the territory of Jetysu). Almaty: "Credo" Publ. (in Russian).

4. Baipakov, K. M., Maryashev, A. N. 2001. In Izvestiya NAN RK. Seriya obshchestv. nauk (News of NAS RK. Social Sciences Series), 1 (230), 53-65 (in Russian).

5. Baitanaev, B. A. 2011. Drevnosti Burgulyuka (Antiquities of Burgulyuk). Almaty: A.Kh. Margulan Institute of Archeology Publ. (in Russian).

6. Baitanayev, B. A., Goryachev, A. A., Egorova, T. A., Ergeshbayev, A. A., Baitanayeva , A. B, Baitanayev, E. B. 2018. In Kazakhstan Archeology, 1-2, 272-287 (in Russian).

7. Goryachev, A. A. 2013. In Beisenov, A. Z. (ed.) Begazy-dandybaevskaya kultura Stepnoy Evrazii (Begazy-Dandybay culture of steppe Eurasia). Almaty: A.Kh. Margulan Institute of Archeology; "Begazy-Tasmola" Publ., 348-370 (in Russian). 
8. Goryachev, A. A., Egorova, T. A. 2015. In Beisenov, A. Z. (ed.) Sakskaya kultura Saryarki v kontekste izucheniya etnosociokulturnyh processov stepnoy Evrazii (Saka culture of Saryarka in the context of studying the ethno cultural processes of steppe Eurasia). Almaty: "Begazy-Tasmola" Publ., 90-99 (in Russian).

9. Kadyrbayev, M. K., Kurmankulov, Zh. 1992. Kultura drevnih skotovodov i metallurgov Sary-Arki (Culture of cattlemen and metallurgists from Sary-Arka). Alma-Ata: "Gylym" Publ. (in Russian).

10. Maryashev, A. N., Goryachev, A. A. 2017. In e-history.kz, 3 (11). URL: http:// edu.e-history.kz/ru/publications/view/723 (in Russian).

11. Smagulov, E. A. 2011. Drevniy Sauran (Ancient Sauran). Almaty: “ABDI Company" Publ. (in Russian).

\section{About the Authors:}

Baitanayev Bauyrzhan A. Doctor of historical sciences, academician of the National Academy of the Kazakhstan, Director, A.Kh. Margulan Archeology Institute, Almaty, Kazakhstan; baytanaev@mail.ru

Goryachev Alexander A. Senior scientific researcher, A.Kh. Margulan Archeology Institute, Almaty, Kazakhstan; aga.2805@mail.ru

Egorova Tatyana. Specialist in Philology, A.Kh. Margulan Archeology Institute, Almaty, Kazakhstan; ega.0108@mail.ru

Baitanayeva Asel B. Bachelor's degree-artist, A.Kh. Margulan Archeology Institute, Shymkent, Kazakhstan; baitasel@mail.ru

Baitanayev Elnar B. Engineer, A.Kh. Margulan Archeology Institute, Shymkent, Kazakhstan; ebaitanaev@mail.ru

Chernov Michael A. Specialist-artist, A.Kh. Margulan Archeology Institute, Almaty, Kazakhstan; mihalapych@yandex.kz

\footnotetext{
Мүдделер қақтығысы туралы ақпаратты ашу. Авторлар мүдделер қақтығысының жоқтығын мәлімдейді. / Раскрытие информации о конфликте интересов. Авторы заявляет об отсутствии конфликта интересов. / Disclosure of conflict of interest information. The authors claims no conflict of interest.

Мақала туралы ақпарат / Информация о статье / Information about the article.

Редакцияға түсті / Поступила в редакцию / Entered the editorial office: 18.12.2019.

Рецензенттер макұлдаған / Одобрено рецензентами / Approved by reviewers: 25.12.2019.

Жариялауға қабылданды / Принята к публикации / Accepted for publication: 08.01.2020.
} 